\title{
Challenges of digitalization for higher education in Russia
}

\author{
Grigory N. Krainov ${ }^{1,2 *}$, Anatoly I. Panov ${ }^{3}$, and Sergei A. Zubkov ${ }^{2}$ \\ ${ }^{1}$ Financial University under the Government of the Russian Federation, Department of Humanities, \\ Moscow, Russia \\ ${ }^{2}$ Russian University of Transport (MIIT), Department of Humanities, Moscow, Russia \\ ${ }^{3}$ Moscow Region State University, Institute of History, Political Science and Law, Moscow, Russia
}

\begin{abstract}
The modern trend of education development is digitalization, transition from conventional classroom offline model to distance online education. Formation of global digital society was accelerated due to the COVID-19 pandemic, when significant portion of Earth population, including students, was forced to work, to study distantly. In this regard, this article discusses the responses of Russian system of higher education to current challenges of digitalization. This article analyzes interactive educational technologies of online, digital, e-learning, visualization and gamification of education, implementation of network structures. On the basis of analysis of the modern state of Russian higher education, the unsolved key issues are demonstrated as well as the main trends of the required changes. This work describes the urgent issues of development of regulatory framework of digital education, intensification of development of digital infrastructure of universities, digital training and further training of teachers and students, analysis and actualization of existing specialties and fields. Solution of the mentioned issues requires for legislative, organizational, administrative, technological, teaching and learning efforts of the country, universities, and society. A response of the Russian system of higher education to the challenges of digitalization can be comprised of formation of unified information and education portal of national universities, designing a model of digital university.
\end{abstract}

Keywords: digitalization of education, digital transformation, online learning, massive open online course (MOOC).

\section{Introduction}

One of the most important innovations of our time is active implementation of online technologies into educational process [1].

However, at present the challenges of digitalization of higher education in Russia have not received an adequate response:

- no efficient theory and methods of e-learning have been developed;

- the digital infrastructure of educational process needs significant updating (some students, especially in the first and second years of study, have no Internet connection).

\footnotetext{
* Corresponding author: krainovgn@,mail.ru
} 
Another urgent task is implementation of optimum all-Russia e-learning platform (similar to Zoom, Teams, etc.);

- the current cycle of technology changes turned to be short, for some economical segments complete changes occur in five-six years. And if at present the learning period of four years (bachelor's degree) or six years (bachelor's degree + master's degree) is justified, then in the nearest future such learning periods will be too excessive [2];

- certain fields and specialties have no prospects for development due to implementation of digitalization into educational process. New principles of development and implementation of educational programs will be required, including digital ones, considering for changes in the market environment;

- digitalization assumes shift away from the conventional form of group classroom learning towards online learning, there occurs the effect of "breaking down the walls of classrooms". This leads to a reduction in the teacher's workload, to further optimization and reduction in the number of teachers in universities (which is painfully happening right now);

- at present, most teachers are not ready for transition to digital education, digital retraining (advanced training) of university teachers is required at special courses, seminars;

- digital revolution provides new opportunities in education, though, is accompanied by serious threats to students, future specialists (the issues of employment, welfare, inequality, etc. become more acute).

In order to be competitive in world academic environment, the competences are required providing skills and habits of work with modern information technologies, skills and habits to develop and to implement digital systems. Are we ready for this? What responses can be given by the higher education in Russia to the challenges of digitalization?

\section{Challenges of digitalization for higher education}

During the First Professor Forum in 2018, the issues of informatization and digitalization of the Russian system of higher education were discussed [3].

Reform of higher education under the slogan of optimization and efficiency improvement was based on managerial principles, the results of university activity were reduced to comparable quantitative indices. The reformers believed that the optimization (decrease in the number of universities, teachers, etc.) should lead to efficiency. In practice this resulted in creation of rigid system of managerial control of universities, subdivision of academic staff into managers (managing administration of the rectorate) and performers-teachers, excessive document flow, elimination of academic standards and traditions [4].

At present, Russia remains a consumer rather than a developer of digital systems and technologies: most electronic products (computers, telecommunication devices, etc.) are supplied from abroad; significant portion of algorithms and software for data acquisition, storage, processing and management were developed by foreign companies. In terms of financing and direct investments into digital equipment and technologies, we are eight times behind advanced countries [5].

The use of digital educational technologies requires for specific skills and habits, competences of teachers capable to efficiently work with overall digital infrastructure, methods of e-learning [6]. For instance, online teaching using video conference assumes ability of teachers to behave in front of the camera, to work with various gadgets, smartphones, etc. However, many teachers are not ready for this. It was demonstrated in [7] that optimization of universities destroyed the natural traditional training chain of personnel of highest qualification from a talented student to professor, academician. 
It should be recognized that under the conditions of digitalization, some educational specialties and areas of training will not be demanded in the future, already at present some professions are not required at labor market. Requests for these or those professions, competences will be formed by market, business environment. Therefore, clear interaction between education, science, and production is required, it is necessary to compile five-year forecasts of economy demands for modern specialists.

Training at various massive open online courses (MOOCs) is becoming more and more popular, their main concept is in rendering available and free education by the best world universities.

The MOOC challenges for higher education are as follows:

- the massive courses are in conflict with the purposes of student-oriented education;

- $\quad$ establishment of feedback between teacher and student is difficult in this case, some of the teaching material remains incomprehensible to the student;

- $\quad$ high percent of self-exclusion is observed: only about $7 \%$ of students participating in the online courses can master all provided types of learning load;

- digital competence of most teachers for efficient application of MOOC is not formed;

- MOOCs are highly expensive tool of online education, their commercialization upon issuing certificates, credit units is in conflict with their title of free courses;

- $\quad$ MOOC is a form of promotion of corporate interests of leading world and national universities, their use will lead to homogenization of higher education, closure of some universities and dismissal of teachers [8].

The issue of online courses in the system of higher education is comprised of difficult quality control and evaluation of students' knowledge. Multiple choice tests are not suitable for disclosure of skills of creative critical thinking of students [9].

The issue of recognition of students' certificates of completion of online courses, allocation of credit units and the like remains unsolved.

\section{Reponses of higher education to challenges of digitalization}

The COVID-19 pandemic accelerated digitalization of educational process, many students were transferred to distance online learning. Under such conditions, the acute issues of digitalization are the existence of the required infrastructure, traffic, Internet speed, legislative regulations of online education. The model of Digital University is currently being developed [10].

In Russia starting from 2012 the Lectorium online platform is in operation, its media center is comprised of several thousands of academic lectures developed by leading teachers and scientists of the country. Universarium interuniversity network platform was created in 2013, which is the data storage of various open e-courses. In 2015 the National Open Education Platform presented Open Education portal, which includes such universities as Lomonosov Moscow State University, St Petersburg University, Moscow Institute of Physics and Technology (MIPT), National University of Science and Technology "MISiS", Higher School of Economics (HSE), Ural Federal University, ITMO University, Peter the Great SpSTU. On the basis of such platforms as One Window (online.edu.ru), WeStudy, GetCourse and others, the open e-courses of leading Russian universities are presented. Popular MOOC providers are American platforms Coursera, edX. Complete online programs for bachelors and masters are being created in HSE, MIPT, RANEPA. They assist students to learn and to obtain certificate about completion of the course [11].

For active inclusion into online education the teachers should possess the following competences: 
- to know national legislative regulations of online learning, as well as pedagogical foundations, theories, technologies and formats of online education;

- to be able to develop and to design pedagogical architecture, content and structure of online courses;

- to have skills of teaching and methodological design of online courses using the advanced Internet technologies, various forms of digital content, as well as evaluation of quality and results of online education [12].

The open online courses will be demanded to obtain supplemental education, further training, for lifelong self-education. The online learning is a tool to solve educational problem but not a solution itself to the problem. The online courses can be adapted for learning disabled persons, for provision of social inclusion, and for foreign students [13].

Therefore, we believe that at present the optimum variant is comprised of the so-called mixed education, upon which the offline learning in the form of open classroom studies will be supplemented, when necessary, with various kinds of online learning. The practice shows that the most efficient are online studies in the form of webinars and video conferences providing direct contact between students and teachers.

A response of the system of higher education in Russia can be formation of information educational portal of Russian universities, designing a model of digital university.

\section{References}

1. N.P. Petrova, G.A. Bondareva, Mir nauki, Kul'tury, Obrazovaniya, 5, 353-355 (2019)

2. N.V. Dneprovskaya, Statistika i Ekonomika, 15(4), 16-18 (2018)

3. G.N. Krainov, Sotsiologicheskiye Issledovaniya, 8, 165-167 (2018). https://doi.org/10.31857/S013216250000772-2

4. G.N. Krainov, Sotsiologicheskie Issledovaniya, 7, 170-172 (2018). https://doi.org/10.31857/S013216250000680-1

5. A. Aptekman, V. Kalabin, V. Klintsov et al., Tsifrovaya Rossiya: novaya realnost [Digital Russia: a new reality]. (McKinsey \& Company, 2017).

https://www.mckinsey.com/ /media/mckinsey/locations/europe\%20and\%20middle $\% 2$ 0east/russia/our\%20insights/digital\%20russia/digital-russia-report

6. N.B. Strekalova, Vestnik Of Samara University. History, Pedagogics, Philology, 25(2), 84-88 (2019). https://doi.org/10.18287/2542-0445-2019-25-2-84-88

7. G.N. Krainov, Sotsiologicheskiye Issledovaniya, 8, 157-161 (2019). https://doi.org/10.31857/S013216250006179-9

8. S.V. Titova, Vysshee Obrazovanie v Rossii, 12, 145-149 (2015)

9. S.A. Zolotukhin, Discussion, 4(56), 97-101 (2015)

10. A. A. Klimov, E.J. Zaichkin, V.P. Chuprynousky, Modern Information Technologies and IT-Education, 15(2), 468-476 (2019)

11. E.D. Larina, Vestnik of Saint Petersburg University. Sociology, 13(1), 102-112 (2020). https://doi.org/10.21638/spbu12.2020.107

12. N.V. Kuznetsov, E-Management, 2(1), 19-25 (2019). https://doi.org/10.26425/26583445-2019-1-19-25

13. V.N. Minina, Vestnik of Saint Petersburg University. Sociology, 13(1), 84-101 (2020). https://doi.org/10.21638/spbu12.2020.106 